\title{
The coexistence of peace and conflict in South America: toward a new conceptualization of types of peace
}

A coexistência entre paz e conflito na América do Sul: em direção a uma nova conceituação dos tipos de paz

JORGE MARIO BATTAGLINO*

Rev. Bras. Polít. Int. 55 (2): 131-151 [2012]

\section{Introduction}

South America is in the midst of a unique phase in its history. Every country in this region is democratic and economic growth has averaged 5.5\% from 2003 through 2008. This unprecedented regional scenario stands in stark contrasts to the recent past of military regimes, chronic economic crisis, and widespread social exclusion. Until the 1980s, every single Latin American country faced unresolved border disputes which often triggered militarized crises and war preparations (Holsti 1996, 150-157; Kacowicz 1998, 67-89; Miller 2007, 317-336). ${ }^{1}$ Notwithstanding, regional peace prevailed in virtue of a normative consensus among countries for the peaceful settlement of disputes (Kacowicz 2005, 71-124). Regional peace was much improved by the 1980s democratization process, which allowed South American countries, particularly in the Southern Cone, to peacefully resolve their still-pending boundary disputes and to increase political, economic, and military cooperation (Kacowicz 1998, 81-83).

Nevertheless, it is remarkable the resilience of the past as there has been an increase in interstate tensions involving both Andean and Southern Cone nations over the last five years. For instance, Colombia, Ecuador and Venezuela have been involved in mutual confrontations which have escalated to the point of threat of armed conflict, the break of diplomatic relations and even the mobilization of troops to bordering areas (McDermott 2009). In addition, the Southern Cone has also been involved in interstate disputes, as showcased by the renewed quarrel over the demarcation of maritime boundaries between Chile and Peru in 2005 (Horna 2009).

\footnotetext{
* Faculty researcher at Universidad Torcuato di Tella and researcher member of the National Scientific and Technical Research Council - Consejo Nacional de Investigaciones Científicas y Técnicas (CONICET) -, Argentina (jbattaglino@utdt.edu).

1 A militarized crisis involves the threat of military force or the display of military force.
} 
This way, how can we define a region that, in spite of its flourishing democracy and deep economic ties, remains involved in boundary disputes for whose resolution the use of force has not yet been discarded? Conventional approaches to zones of peace are based on the traditional, broad classification of areas of negative and positive peace (Galtung 1975). This dichotomous classification has been subsequently reformulated to better capture different gradations of negative and positive peace (Holsti 1996, 157-158; Kacowicz 1998, 8-11; Miller 2007, 44-48; Oelsner 2007, 263-265). Essentially, the main criterion for distinguishing between zones of negative and of positive peace is the possibility of the use of force by states (Miller 2007, 42-43). Normally, traditional classifications of zones of peace contemplated two main situations regarding the regional use of force. While in zones of negative peace the use of force is possible and, depending on the gradation of the negative peace, even imminent, in zones of positive peace, the use of force is very unlikely. Regions of negative peace are characterized by distrust, arms races, and military competition. Under negative peace there are preparations and contingency plans for war. Furthermore, these zones are characterized by the predominance of nondemocratic regimes and by a low level of economic relations (Martin 2006, 124-144). Even though peace has still been maintained in that kind of context, its quality has been actually low, since war has never been completely ruled out (Kacowicz 1998, 67-81). Conversely, zones of positive peace are defined by the presence of confidence and trust. States do not prepare for an armed conflict with neighboring countries, nor do they expect other states in the zone to do so. This context is mostly associated by the presence of democratic rule and strong economic relations between countries (Doyle 1997; Oneal and Russett 1997). Although the impact of democracy and economic relations on the emergence of a zone of positive peace is still unclear, the presence of these two factors has had a positive impact on the quality of the peace, making these zones free from the use of force (Kacowicz 1998, 98-99).

This article contends that the resurgence of interstate disputes in the region poses an important challenge to mainstream literature which understands zones of peace largely in dichotomous terms. Certainly, the dichotomous classification - and its subsequent reformulations - has limitations when explaining this coexistence of factors. In other words, the concepts of positive and negative peace are not accurate enough for describing the foundations of the zone of peace, particularly in the Andean sub-region of South America. To characterize the latter as a zone of positive peace entails a major shortcoming, since in the areas of positive peace the threat, display, or use of force is ruled out as a mean to resolve disputes between states. The latter does not seem to be the case in this region, where Colombia, Ecuador and Venezuela experienced many militarized crises during the last years. Likewise, it would be inaccurate to define this region as a zone of negative peace, because democracy and strong economic relations, which are variables generally not present in zones of negative peace, have contributed decisively to improving 
the quality of peace in the Andean area by making war and other kinds of armed conflict very unlikely.

In this sense, the main limitation of these conceptualizations is that the criterion "possibility of use of force," although useful to differentiate zones of negative peace from zones of positive peace, cannot account for a "third" situation: for those zones where the use of force is not discharged by states to resolve disputes (as in the zones of negative peace), but where the actual use of force is very unlikely (as in zones of positive peace). This particular coexistence of factors cannot be properly accounted by the dual character of the "use of force" standard used by mainstream views on zones of peace. Since they have established only two possibilities, the use of force is still possible in zones of negative peace and unlikely in positive ones. This dual criterion cannot explain the enduring overlap of militarized crises and peace. In order to clarify this singular blend of factors, a more detailed classification of the full spectrum of "uses of force," which is possible to expect between states, is needed. A more nuanced conceptualization of the varieties of the "use of force," going beyond the dual norm, would be crucial to establish an extended categorization of zones of peace, which could account for the security dynamics in that third situation common to the Andean region.

The main purpose of this article is to address this conceptual vacuum by way of developing a new analytical category of regional peace: the hybrid peace. Hybrid peace refers to the coexistence between key dimensions of both negative and positive peace. It is due to this coexistence that the security dynamics of hybrid peace are conceptually different from those found in zones of negative peace or positive peace. For instance, while war is not improbable in zones of negative peace, it is very unlikely in zones of both positive and hybrid peace. However, the factor that distinguishes the latter zones from the ones of positive peace is the possibility to expect the occurrence of militarized crises, since disputes have not yet disappeared from zones of hybrid peace. The type of force expected in these zones is related to their peace foundations. In this way, hybrid zones exist because of the persistence of unresolved disputes in the context of democratic renaissance, growing economic relations and a renovated set of regional institutions for the peaceful settlement of disputes. These peace foundations account for distinctive security dynamics that consist in the event of militarized crises contained by the restricting effect of the above-mentioned conditions.

The structure of the article follows logically from the preceding argument. The first section provides a review of the traditional approaches to the South American peace zone and its shortcomings to explain the current condition of the security in the region. The second part will identify the main dimensions involved in the classification of zones of peace in order to introduce the concept of hybrid peace. The final part will examine the evolution of security in South America during the previous century, taking into account the newly-introduced typology of peace zones: negative, hybrid, and positive. 


\section{Approaches to regional peace}

The study of peace zones in South America emerged in the early 1990s and was largely influenced by the traditional distinction between zones of negative and positive peace. The first authors to analyze this region based on this perspective were Holsti (1996) and Kacowicz (1998). This dichotomous classification has been progressively expanded in order to capture historical and contemporary variations of peace in different regions (Holsti 1996, 157-161; Kacowicz 1998, 29-65; Miller 2007, 41-48; Oelsner 2007, 262-265) (see Table 1). For instance, Holsti defines South America as a non-war zone or as a negative peace for most of the $20^{\text {th }}$ century (Holsti 1996, 157). Similarly, Kacowicz agrees with the concept of negative peace, yet derives two subtypes from the positive peace type, that is, the stable peace and the security community (Kacowicz 1998, 60). Finally, more recent studies have developed a newly-expanded typology. Miller provides a further analytical division of positive peace (normal peace and high-level peace), whereas in the case of the negative peace he suggests the types of cold war and cold peace (Miller 2007, 44-47). Oelsner divides negative peace into fragile, unstable, cold, or conditional peace; and derives stable peace and security community from positive peace (Oelsner 2007, 263-264).

Table 1. Traditional classifications of negative and positive peace.

\begin{tabular}{|c|c|c|c|c|c|c|c|}
\hline & Holsti & Kacowicz & Miller & Oelsner & $\begin{array}{l}\text { Security } \\
\text { Dilemma } \\
\text { intensity }\end{array}$ & $\begin{array}{l}\text { Use of } \\
\text { force }\end{array}$ & $\begin{array}{l}\text { Type of } \\
\text { conflict } \\
\text { expected }\end{array}$ \\
\hline $\begin{array}{l}\text { Negative } \\
\text { peace }\end{array}$ & $\begin{array}{l}\text { - Negative } \\
\text { peace }\end{array}$ & $\begin{array}{l}\text { - Negative } \\
\text { peace }\end{array}$ & $\begin{array}{l}\text { - Cold war } \\
\text { - Cold } \\
\text { peace }\end{array}$ & $\begin{array}{l}\text { - Fragile } \\
\text { peace } \\
\text { - Unstable } \\
\text { peace } \\
\text { - Cold peace }\end{array}$ & \multirow[t]{3}{*}{ High $\boldsymbol{A}$} & - Likely & $\begin{array}{l}\text { - War } \\
\text { - Intermediate } \\
\text { armed } \\
\text { conflict } \\
\text { - Minor } \\
\text { armed } \\
\text { conflict } \\
\text { - Militarized } \\
\text { crisis }\end{array}$ \\
\hline $\begin{array}{l}\text { Hybrid } \\
\text { peace }\end{array}$ & & & & & & $\begin{array}{l}\text { - Still } \\
\text { probable }\end{array}$ & $\begin{array}{l}\text { - Militarized } \\
\text { crisis }\end{array}$ \\
\hline $\begin{array}{l}\text { Positive } \\
\text { peace }\end{array}$ & $\begin{array}{l}\text { - Pluralistic } \\
\text { security } \\
\text { community }\end{array}$ & $\begin{array}{l}\text { - Stable } \\
\text { peace } \\
\text { - Security } \\
\text { community }\end{array}$ & $\begin{array}{l}\text { - Normal } \\
\text { peace } \\
\text { - High-level } \\
\text { peace }\end{array}$ & $\begin{array}{l}\text { - Stable } \\
\text { peace } \\
\text { - Security } \\
\text { community }\end{array}$ & & - Unlikely & $\begin{array}{l}\text { - Armed } \\
\text { conflict very } \\
\text { unlikely }\end{array}$ \\
\hline
\end{tabular}

The main criterion used by those authors for distinguishing among types of positive and negative peace is the likelihood in the use of force to resolve interstate disputes. For example, the concept of cold peace (a negative peace subcategory 
for Miller and Oelsner, which is the closest to the positive peace) is defined as a situation in which states have not yet ruled out the possibility of using force against neighbors. Consequently, military planning and weapons acquisitions continue to be driven by the potentiality of a war with neighbors (Oelsner 2007, 264; Miller 2007, 45-46). In this sense, the main distinction between cold peace and the other subtypes of negative peace is that the security dilemma is more intense in the latter case - either because states have recently been at war, or because the imminence of war is far more acute than in cases of cold peace. Yet, war has not been ruled out completely within the category of cold peace.

Although the idea of an emerging security community, or of stable peace, is a close depiction of the Southern Cone peace zone (Hurrell 1998, 137-154), it would not be accurate to include the Andean region in such a type, since their countries maintain border disputes, have broken diplomatic relations and still maintain conflict scenarios with their neighbors. Nevertheless, defining the Andean region as a zone of negative peace underestimates the impact of democracy, strong economic relations, and a normative consensus for the peaceful settlement of disputes, on the likelihood of the use of force against neighboring countries.

These conceptualizations' main drawback is that the values of the criterion "possibility of use of force" (imminent/likely for the case of negative peace and unlikely/very unlikely for the case of positive peace) cannot account for those situations where states do not discharge the use of force to resolve disputes; but where the effective use of force is unlikely or, more precisely, only limited to the threat or display of military force. This lack of complexity for distinguishing zones of peace underestimates the positive impact that democracy, economic relations, and regional institutions have on the possibility of the use of force by states.

In other words, the Andean region's categorization as a zone of negative peace minimizes the crucial impact that democracy, economic relations, and institutions have in restricting the use of force, exclusively, for militarized crises. In this sense, the incorporation of a third category of peace, the hybrid one, would require an expanded conceptualization of the criterion "use of force." This clarification should include not only a classification of the different uses of force expected between states, but also an analysis on how they are related to different peace foundations.

A widely well-known classification of conflict between states is the Armed Conflict Dataset of the Uppsala Conflict Data Program. This dataset distinguishes between three types of conflicts - war, intermediate armed conflict, and minor armed conflict. "War" involves at least 1,000 battle-related deaths per year; "intermediate conflict" has between 25 and 1,000 deaths per year and a cumulative total for the entire conflict of at least 1,000 deaths, but fewer than 1,000 in any given year; and "minor armed conflict" has at least 25 deaths per year and fewer than 1,000 deaths accumulated during the course of the conflict. The incorporation of the category "militarized interstate crisis" to this classification is relevant since 
the logic of the use of force in zones of hybrid peace is usually restricted to that kind of dynamics. Militarized interstate disputes are "cases of conflict in which the threat, display or use of military force short of war by one member state is explicitly directed towards the government, official representatives, official forces, property, or territory of another state. Disputes are composed of incidents that range in intensity from threats to use of force to actual combat short of war" (Jones 1996).

The expected level of conflict in zones of peace is related to their foundations. Zones of negative peace are featured by weak peace foundations, which make the use of military force in their entire spectrum from war to militarized crisis more likely. Conversely, the foundations of zones of positive peace encourage a peaceful settlement of disputes. In zones of hybrid peace, countries do not discard the possibility of a military conflict, the political discourse can be belligerent, force can be displayed via troops mobilization to borders, and arms purchases are made based on a possible confrontation with neighboring countries (Hirst 2003; Kahhat 2008). Although neither diplomatic crisis nor permanent references to the possibility of war can be dismissed, in these zones countries never resort to war or to an intermediate/minor armed conflict to resolve a dispute (Table 1) since democracy, economic relations, and regional institutions limit that possibility.

\section{The foundations of peace zones}

Conditions that encourage or prevent the use of force among states in a given region have been extensively studied by the zones of peace approach. Although realism and liberalism have their own explanations on the sources of peace and conflict, some authors have argued that the combination of both theories is a promising way to deal with peace foundations (Kacowicz 1998; Miller 2007). In this way, these authors dismiss both realist and liberal approaches as they considered them ill-suited to account for the persistence of peace in South America. Kacowicz argues that "conventional theories of international relations do not provide a comprehensive explanation for the phenomenon of peace zones" $(1998,2)$. Miller contented that traditional approaches could be worked in tandem for explaining the different gradations of regional peace. For instance, the presence of realist variables (such as balance of power strategies or the persistence of territorial or ideological conflicts) and the absence of those linked to liberalism (democratic regimes, high levels of commercial trade, or regional institutions to process conflicts) are generally associated with zones of negative peace (Miller 2007, 21-23). This approach would be used to connect five different types of peace foundations with different uses of force expected in each zone of peace (Table 2). 
Table 2. Types of peace in South America, 1900-2010.

\begin{tabular}{|c|c|c|c|}
\hline $\begin{array}{l}\text { Types of peace/ } \\
\text { Peace foundation }\end{array}$ & $\begin{array}{l}\text { Negative peace (and } \\
\text { subcategories) }\end{array}$ & Hybrid peace & $\begin{array}{l}\text { Positive peace (and } \\
\text { subcategories) }\end{array}$ \\
\hline $\begin{array}{l}\text { Satisfaction with the } \\
\text { status quo }\end{array}$ & - Passive & - Passive & - Active \\
\hline Security dynamics & $\begin{array}{l}\text { - Internal/external } \\
\text { balance of power } \\
\text { - Immediate deterrence }\end{array}$ & $\begin{array}{l}\text { - General deterrence } \\
\text { - Emerging military } \\
\text { cooperation }\end{array}$ & $\begin{array}{l}\text { - Military cooperation } \\
\text { - Emerging military } \\
\text { integration }\end{array}$ \\
\hline Type of regime & $\begin{array}{l}\text { - Alternating democratic } \\
\text { and authoritarian } \\
\text { regimes }\end{array}$ & - Democracy & - Democracy \\
\hline Economic relations & - Reduced bilateral trade & $\begin{array}{l}\text { - High bilateral trade } \\
\text { - High levels of } \\
\text { investment }\end{array}$ & $\begin{array}{l}\text { - High bilateral trade } \\
\text { - High levels of } \\
\text { investment }\end{array}$ \\
\hline $\begin{array}{l}\text { Type of regional } \\
\text { norms }\end{array}$ & $\begin{array}{l}\text { Norms to resolve } \\
\text { conflicts peacefully }\end{array}$ & $\begin{array}{l}\text { - Strong tradition for the } \\
\text { peaceful settlement of } \\
\text { disputes } \\
\text { - Security norms }\end{array}$ & $\begin{array}{l}\text { - Strong tradition } \\
\text { for the peaceful } \\
\text { settlement of disputes } \\
\text { - Security norms }\end{array}$ \\
\hline Cases & $\begin{array}{l}\text { - Argentina-Brazil-Chile } \\
\text { until the end of the } \\
\text { 1980s } \\
\text { - Bolivia-Chile-Peru } \\
\text { until } 1990 \\
\text { - Venezuela and } \\
\text { Colombia until } 1990\end{array}$ & $\begin{array}{l}\text { - Colombia and Venezuela } \\
(1990-) \\
\text { - Peru and Chile (1990-) } \\
\text { - Chile and Bolivia from } \\
\text { 1990-) }\end{array}$ & $\begin{array}{l}\text { - Argentina-Brazil- } \\
\text { Chile (1990-) }\end{array}$ \\
\hline Expected use of force & $\begin{array}{l}\text { - Considerable likelihood } \\
\text { of escalation to war or } \\
\text { to intermediate/minor } \\
\text { armed conflict }\end{array}$ & $\begin{array}{l}\text { - Militarized crises are } \\
\text { still likely } \\
\text { - War, intermediate and } \\
\text { minor armed conflicts } \\
\text { are unlikely }\end{array}$ & $\begin{array}{l}\text { - Militarized crises and } \\
\text { armed conflicts are } \\
\text { unlikely }\end{array}$ \\
\hline
\end{tabular}

Satisfaction with the status quo: the satisfaction with the status quo refers to the degree of agreement that the states have toward the set of diplomatic, political, military, and economic rules that govern a system or subsystem. The existence of unresolved territorial or ideological disputes between states is usually referred as the most important source of state dissatisfaction with the status quo. Satisfaction is passive when there are unresolved territorial conflicts or disagreement over the rules governing the system. Satisfaction that comes from passivity is common in situations of negative or hybrid peace. States are actively satisfied with the status quo when there are no territorial or ideological disputes or, if they exist, they are irrelevant to interstate relations. When satisfaction is active, countries would not militarize their bilateral relations. Positive peace, or any of its 
subcategories, only exists when all states are actively satisfied with the status quo (Kacowicz 1998, 47-50).

Security dynamics: it refers to the predominant interaction between states in the area of military security (Buzan, Waever, and De Wilde 1998, 49-70). In zones of negative peace, states are normally immersed in a logic of "internal or external balance of power," that is, when they attempt to maintain, via domestic buildup or external alliances, their relative military capabilities vis-à-vis other states. Military competence or the outbreak of arms races is common in those cases. In zones of hybrid peace, on the contrary, states opt for "general deterrence" as their principal defense strategy. It refers to a policy of regulating an adversarial relationship between two states through the maintenance of a satisfactory level of forces aimed at raising the cost of an eventual military aggression from a neighboring country. This kind of strategy is implemented when state actors perceive that war is unlikely and, consequently, the maintenance of a classic balance of military power is not economically feasible or worthy. Therefore, countries in zones of peace renounce to maintain their relative military capacities vis-à-vis other states (Schweller 2004). Finally, the main security dynamics in zones of positive peace is military cooperation. In these zones, the use of force is no longer an option; on the contrary, military cooperation is the predominant security relation between states. In addition, states begin to practice different forms of military integration.

Type of regime: theories about peace zones define democracy as a factor that improves the quality of the peace (Kacowicz 1997; Miller 2007). Some studies focus on democratic norms and argue that a liberal democratic culture can make leaders become used to negotiation and compromise (Russet 1993, 1996). Additionally democracy can promote peace because democratic leaders try to eliminate conflict hypotheses in order to reduce domestic military power (Buzan and Weaver 2003, 325-327). Other studies focus on political structures; democratic governments face institutionalized constraints that hamper their capacity to mobilize the state's resources for war without the consent of a broad number of actors (Russett 1993, 30). A recent strand of neoclassical realism sustains that democracy promotes peace through means not contemplated by the mainstream literature on democratic peace. Related to this, democracy generates a wealth of information about a state's motivations because of its transparency during its policymaking process (Kidd 1997). This implies that if a state has peaceful or aggressive intentions towards their neighbors, the democratic process will reveal it. This democratic feature may contribute to an early intervention of other states and regional institutions that will prevent conflicts from escalating and/or appease the aggressor.

Economic relations: liberals suggest a positive link between the expansion of economic relations between states, mainly trade and investment, and peace. A series of works suggested that high level of commercial exchange reduces the incidence of militarized disputes (Doyle 1997; Mansfield and Pollins 2001; Russett and Oneal 2001). A recent strand of the interdependence approach argues that 
the level of direct foreign investment between states is an important variable to explain regional peace; the greater the volume of trade and investment between two countries, the more interest these countries will have in avoiding conflict (Rosecrance and Thompson 2003). The level of economic relations does not seem to have been an important variable to explain the maintenance of negative peace in South America, since peace persists in a context of a low level of economic exchanges (Martin 2006). Nevertheless, the increase of both bilateral trade and investment are factors that have contributed to the consolidation of hybrid and positive peace zones through the formation of a dense interrelated network of social and economic actors whose main interest is the maintenance and expansion of economic relations, which demands a predictable and peaceful context.

Type of regional norms: According to Kacowicz $(2005,166)$ "the normative framework has been relevant in the maintenance of long peace in South America." Norms contribute to the formation of identities and interests; the institutionalization of these norms improves communication between states, reducing uncertainty about intentions and increasing the capacity of governments to make credible, binding commitments to one another (Keohane 1984). Kacowicz (2005) identified five types of international norms that have favored regional peace in South America: 1) common interests and values, 2) sovereignty and equality of states, 3) uti possidetis and territorial integrity, 4) peaceful settlement of international disputes, and 5) arms control, collective security, and ConfidenceBuilding Measures (CBMs). In Latin America, these rules "have been formalized in an intricate network of formal institutions that have regulated the relations of Latin American nations" (Kacowicz 2005, 63). Negative peace has persisted in South America due to the pacifying effect that this set of rules has had over the behavior of states. In the past 20 years, the amount of norms in this region has expanded considerably, especially those related to the peaceful settlement of international disputes and those who foster the building of regional defense institutions. The presence of new regional institutions and their capacity to prevent and resolve interstate disputes is a distinguishing feature of hybrid peace zones and of positive peace ones.

Although zones of negative peace were maintained in South America despite the absence of democracy during most part of the $20^{\text {th }}$ century, its rapid diffusion in the 1980s substantially improved the quality of peace (Kacowicz 1998, 2005). It is precisely for this reason that democracy is a variable that contributes to explain the consolidation of hybrid and positive peace zones. Certainly, positive peace has lasted in the Southern Cone because democratic regimes have been able to settle border disputes. However, zones of hybrid peace show that territorial or ideological disputes endure, even in a militarized fashion, but that the actual use of military force is unlikely to resolve it. Democracy does not necessarily guarantee the resolution of boundary issues, but it does reveal state's intentions and it certainly encourages governments to support new regional institutions of 
conflict resolution while forcing leaders to be more sensitive to the interests of both citizens and economic groups, which are increasingly favored by the expansion of trade and investment relations.

In the South American zone of negative peace, armed conflict was usually a possible alternative and, in many cases, it was even imminent when it came to resolving conflicts. Regional peace was maintained mainly by the presence of norms of peaceful settlement of disputes (Kacowicz 1998, 2005). Admittedly, peace prevailed during most part of the $20^{\text {th }}$ century in spite of the poor economic relations or the complete absence of these among states and despite the predominance of nondemocratic rules (Martin 2006, 117-148). The existence of unresolved disputes favored the maintenance of conflict hypotheses and of military deployment oriented to an eventual war with neighboring countries.

In the hybrid zone of peace, states uphold different kinds of territorial and ideological disputes, they may consider the possibility of using force and they deploy and organize their armed forces' missions in the light of a potential conflict with neighbor countries. Militarized crises have not yet disappeared and when they break out countries can mobilize troops to their borders and their leaders' speech can be bellicose. Nevertheless, the use of military force in zones of hybrid peace is unlikely. This is due to the combined effect of three factors that prevent a military escalation from taking place. The first factor is that the predisposition of democratic leaders towards negotiation and compromise has favored not only the adherence to new regional institutions of conflict settlement, but also a greater willingness to bilateral negotiation with their neighbors. Moreover, democratic politics reveals states intentions and leaders motivations because of the ample circulation of information about military doctrine, deployment, and weapons acquisitions, which can foster an early involvement of regional institutions. The second element is the increasing level of economic relations, which strengthens the interest of domestic groups in maintaining and deepening the status quo. Finally, the third reason is the fact that the framework of norms that foster the preservation of peace is not only present but its importance has been enhanced by the creation of new political and defense regional institutions such as Union of South American Nations (UNASUR) and the South American Defense Council (SADC). This reinforced institutional framework contributes to build confidence and certainty, and favors communications between governments. The interaction of these three factors have prevented the escalation of conflicts in these zones and have limited the use of force to the level of display of military force in the course of a militarized crises.

The resolution of territorial or ideological disputes, or its irrelevance in bilateral relations, is the aspect that defines the pathway from hybrid to positive peace. In the latter, countries abandon the idea of military conflict with their neighbors and, therefore, security relations are no longer based on military balance 
or deterrence. Subsequently, security relations start to shift towards cooperation and emerging processes of military integration.

\section{The prevalence of Negative Peace in South America, 1900-1980}

South America was plagued with military conflicts during the $19^{\text {th }}$ century (Centeno 2002). However, during the $20^{\text {th }}$ century, the amount of wars and disputes decreased; there were only two interstate wars, Bolivia-Paraguay in 1932 1935 and Peru-Ecuador in 1941 (Holsti 1996, 154). Since 1941 there have been no interstate wars among countries in the region, although minor armed conflicts between Peru and Ecuador did take place in 1981 and 1995. Nonetheless, all the countries in the region faced unresolved territorial disputes during this period. As a result, states did not rule out the possibility of using force against neighboring countries, revealing the existence of an intense security dilemma. Consequently, arms races, arms competitions, and informal alliances were common in this period (Holsti 1996, 154-157).

The scarcity of wars during the $20^{\text {th }}$ century led South America to be defined as "the most peaceful region in the world" (Holsti 1996, 155). The main cause of this "long regional peace" was the shared normative consensus for the peaceful settlement of international disputes that prevailed among South American nations (Kacowicz 1998, 2005). Holsti $(1996,156)$ argues that "no other region of the world has as many bilateral and multilateral documents, treaties and charters imposing obligations for the peaceful settlement of disputes."

In spite of this normative consensus, the probability of a war among the most powerful South American countries was not only high but, to a large extent, imminent throughout this period. Argentina and Brazil experienced an intense rivalry during most part of the $20^{\text {th }}$ century. The competition became more intense during the Second World War, when both countries were on the brink of a war, and later escalated during the 1960s and 1970s, when these countries were immersed in a nuclear arms race. Similarly, Argentina and Chile sustained a prolonged border dispute that nearly provoked a war in 1978. War was also imminent in the cases of Chile-Peru (1975), Ecuador-Peru (1935, 1991), and Colombia-Nicaragua (1979).

Critics have contended the liberal theories' arguments on negative peace. Democracy and economic relations have been mostly absent in South America during a great part of the $20^{\text {th }}$ century yet peace still prevailed in this region (Kacowicz 1998; Martin 2006; Dominguez 2003).

However, democratization and increasing economic relations, during the 1990 s, were factors that positively contributed to the transformation of negative zones of peace into areas of hybrid peace. Countries of the latter zones have displayed a degree of compromise and confidence towards their neighbors greater 
to the levels present in zones of negative peace. This is because democratic leaders are both more willing to negotiate with their counterparts and are more predisposed to create or join regional institutions for conflict resolution. Similarly, they are also more likely to pay attention to the voice of economic and social actors, either for economic interests or electoral reasons, who generally favor the maintenance of peace.

\section{Hybrid peace in South America, 1990-2010}

Zones of hybrid peace are characterized by the simultaneous presence of: 1) unresolved disputes that may become militarized, yet without escalating to an intermediate armed conflict or war; 2) democracies that maintain dense economic relations with their neighbor countries; and 3) regional norms and institutions (both old and new) that help to resolve disputes peacefully. The most relevant cases of hybrid peace in South America are Chile-Peru since 1990 and ColombiaVenezuela since $1991 .^{2}$

The return of full democratic regimes to the above-mentioned countries is a key indicator of the formation of a zone of hybrid peace. The emergence of democracy, in those countries, was linked to a sustained increase in trade and financial relations. Both factors have enhanced the quality of the existing peace. Trade involving Venezuela and Colombia increased 100\% between 1990 and 2000 and $300 \%$ between 2000 and 2008 (IADB 2011). Colombia is currently the second largest market for exports from Venezuela and vice versa. Moreover, the first section of a gas pipeline, which supplies Colombian gas to western Venezuela, was inaugurated in October 2007. This kind of energetic interconnection suggests a long-term commitment of governments in what concerns regional stability (Rosecrance and Thompson 2003, 384-390). Similarly, in the period 1993-2005 the total exports from Peru to the world quadrupled. In this same period, exports to Chile increased eleven times (Fairlie, Queija, and Rasmussen 2007, 113). Similarly, trade between Chile and Peru rose from US\$ 648 million in 2001 to US\$ 2,950 million in 2008 (IADB 2011a). Currently, Peru is the second destination of foreign investments from Chile with an accumulated amount of US\$ 9,999 million by 2010 (Government of Chile 2011). Similarly, Chile is the main destination of Peruvian foreign investments with an accumulated amount of US\$ 3,000 million (Peru 21 2010).

Certainly, it is possible to expect an increase in the trade between both Chile-Peru and Colombia-Venezuela due to tariff advantages, low transportation costs and the complementary nature of their economies. This positive expectation about future commerce is an extraordinary incentive for keeping regional peace (Copeland 1998).

2 It is considered that the outbreak of the "Caracazo" in 1989 and the Constitutional Reform of Colombia in 1991 are turning points that represent the beginning of a new era of democratization in both countries. 
Zones of hybrid peace are also characterized by a renewed process of regional institutional building fostered by the predisposition for negotiation by democratic regimes. In this way, the Southern Cone has undergone a process of institutional strengthening for the prevention and resolution of conflicts led by Brazil through initiatives such as UNASUR and SADC. Although the mere existence of those institutions does not guarantee the resolution of conflicts, it can contribute to the development and institutionalization of new dynamics that facilitate their prevention and management. The new SADC plan for the years 2010-2011 envisages different actions for conflict prevention and for the reduction of regional uncertainty: 1) establishing a mechanism for consultation and providing instant information about situations that put regional peace at risk; 2) developing a common methodology for measuring UNASUR defense spending; 3) devising common procedures for the implementation of confidence-building measures (SADC 2010).

In terms of conflict management, UNASUR and the SADC are institutional settings for regional negotiation in which members can be quickly summoned. Additionally it has the flexibility to deal with a wide range of defense-related issues. These features have come more apparent since the attempt to deploy US troops in Colombian bases in March 2009. Neighboring nations were concerned that Colombian bases would be used as a platform to increase US military control over the region. The rest of the countries made clear their vehement opposition to the decision of Colombia to expand cooperation with the US. As a reaction to that future deployment, South American Presidents and defense and foreign relations ministers quickly cancelled prior commitments and within a few days organized two consecutive meetings. The first in Argentina included all the UNASUR presidents, while the second, in Ecuador, called the defense and foreign affairs ministers of the SADC. The final document of the meeting includes a rejection of foreign military threats to the sovereignty of the member nations.

These dynamics contributed not only to the de-escalation of the crisis, but also to the establishment of a system of defense consultation, discussion and negotiation, which could become precedent in dealing with crises to come. UNASUR and SADC intervention was critical for the release of the secret agreement that Colombia had signed with its northern partner affording the later use of its bases. The disclosure of the agreement considerably reduced the level of regional tension since it revealed that the US troops would not be operating outside of Colombia.

However, the process of democratization, the growing economic relations, and the regional institutional framework have failed to resolve territorial disputes or to dismiss the organization and deployment of the armed forces in the light of a potential military conflict with neighbor countries. Nonetheless, the presence of these factors should not be neglected since their existence and interaction can prevent armed conflicts and limit the escalation of militarized crises in at least two different ways. 
First, democratic leaders are more inclined both to negotiate with counterparts and to accept and participate in regional institutions, which are key actors for resolving conflicts. As a case in point, South American leaders have established, for the first time in its history, a regional institution (UNASUR) that plays a crucial role in de-escalation of the frequent crises between Colombia and Venezuela/ Ecuador. Leaders' predisposition to negotiation was demonstrated in the various crises faced by Colombia and Venezuela. The bellicose rhetoric that the presidents showed during the various crises was promptly followed by a natural willingness to negotiate. The latest crisis broke out in July 2010 when President Uribe denounced the presence of camps of Fuerzas Armadas Revolucionarias de Colombia (FARC), the Revolutionary Armed Forces of Colombia, on Venezuelan soil. After a few days of diplomatic skirmishes, the UNASUR intervened successfully. On July 22, the president of both countries signed the Declaration of Santa Marta in which they promised to "re-launch bilateral relations restoring diplomatic relations between both countries based on a transparent and direct dialogue, favoring diplomatic pathways" (Smink 2010). Similarly, democratic leaders' predisposition to negotiation is also confirmed by the Chile and Peru decisions to submit their maritime dispute to the International Court of Justice in The Hague. Both countries declared that they are willing to accept the Court's ruling regardless of its outcome (Salazar 2010).

Secondly, democracy favors hybrid peace because it reveals the military intentions of neighboring states. In particular, the electoral process, and the interaction between the executive and legislative and bureaucratic politics can disclose plenty of information about the military posture of a state (Kydd 1997, 128-139). In other words, in a democracy, it is difficult to hide preparations for a military action because the democratic process would reveal it. Certainly, there is no guarantee that a democracy will always have peaceful intentions. But even in the worst-case scenario, the main effect of this kind of regime would be to act as an early prevention mechanism that will foster the intervention of regional institutions to impede the conflict outbreak or its escalation.

Hybrid peace's conditions not only limit the escalation of militarized crisis, but also restrict defense relations exclusively to the realm of general deterrence. This kind of strategy has been implemented by South American countries such as Colombia or Peru since they have not balanced the weapons acquisitions of Venezuela and Chile.

Chilean purchases triple those of Peru. Furthermore, the type of weaponry incorporated by Chile gives this country a clear relative military advantage over Peru. Chile acquired 316 Leopard tanks, 2 submarines, 8 frigates, and 42 F-16 fighter jets. Peru's response to Chile's purchases was the acquisition of two used frigates from Italy, the modernization of its military aircraft, and the acquisition of anti-tank missiles. The same pattern can be observed in the case of Colombia and Venezuela. Venezuela's purchase of $24 \mathrm{Su}-30$ aircraft and last-generation 
missiles and submarines did not provoke an equivalent response of Colombia, who decided to buy used Kfir aircraft adapted for counter-insurgency missions.

This lack of response by Peru and Colombia, vis-à-vis the significant weapon acquisitions of Chile and Venezuela, reveals that changes in relative military capacities are no longer perceived as a security problem in zones of hybrid peace. However, the fact that the acquisition of Chile and Venezuela did not provoke any equivalent response from Peru and Colombia should not be perceived as an indicator of these countries accepting their military weakness, but rather as a rational response to a regional context in which war, and intermediate and minor armed conflicts are unlikely.

\section{The emergence of positive peace}

The evolution of positive peace in the Southern Cone has had three main phases. During the first one, states launched a process of negotiation to resolve boundary disputes. The second was primarily economic and was characterized by the signature of trade agreements and the substantial increase in economic relations, especially in trade and investment. Finally, states began a process of military cooperation that eventually led to the elimination of conflict hypotheses.

The positive peace zone began to take shape in the Southern Cone when Argentina, Brazil, and Chile resolved their border disputes (Buzan and Weaver 2003, 322-327). The return of democracy in the mid-1980s fostered and strengthened the process of cooperation between Argentina and Brazil (Kacowicz 1998, 81-89, 117-121). Relations between Argentina and Chile followed a similar path. The resolution of the pending border issues fosters a significant increase in economic relations (Fuentes 1996). Trade between the two countries grew systematically after the treaty was signed in 1984. Argentina became the main destination for foreign investment from Chile with a total amount of US\$15,900 million between 1990 and 2010. This represents $28 \%$ of Chile's total investments abroad (Government of Chile 2011a).

The positive foundations of peace in the Southern Cone became evident with the so-called "gas crisis" of 2004, when Argentina had to cut down its gas shipments to Chile. In some months, the shipments were reduced to almost zero because Argentina privileged the supply of gas to its own growing domestic demand. This affected significantly the activity level of Chile's economy, heavily dependent on Argentinean gas. However, the conflict was negotiated and resolved in a political way; relations between both countries were not altered and militarized discourse, common in the recent past and foreseeable for the kind of issue at stake, was absent during the entire crisis.

As a matter of fact, security relations between countries in the Southern Cone have improved substantially since the 1980s. Democracy has had a favorable impact on the security situation in this zone. The challenges faced by new democracies in 
Argentina (1983) and in Brazil (1985) contributed to creating a sense of common vulnerability, especially in regard to the power of the armed forces (Buzan and Weaver 2003, 325). Both countries used to maintain reciprocal conflict hypothesis by the mid-1980s, which was seen by the newly-democratic authorities as a source of domestic and economic power for the military. In this sense, the deepening of economic, political, and military relations were perceived by the democratic leaders as a strategy to reduce military power and assert civilian control. In this way, Argentina eliminated its conflict hypothesis with Brazil at the end of the 1980s and Brazil followed that measure in 1996, beginning a process of relocation of military units from its Argentinean border to the Amazon (Zirker and Martins 2000). In this connection, the CBMs, such as joint maneuvers or officer exchanges, have increased considerably since 1995. Moreover, Argentina and Brazil established the Argentine-Brazilian Mechanism for Coordination of Security and Defense (MCSD). The MCSD is a forum for policy coordination on security matters which includes a Mechanism of Strategic Analysis whereby national agendas of international security are put forth and debated (Flemes 2005).

Relations between Argentina and Chile also experienced significant progress in the realm of defense. Between 2002 and 2008, 45 joint military exercises were carried out. In 2001, both states developed a common methodology to measure defense expenditures with support from the Economic Commission for Latin America (ECLA). This initiative was unprecedented worldwide and it had a great impact at the regional level. In what concerns the bilateral level, there is a mechanism of annual conferences between the ministers of defense and foreign affairs of Chile and Argentina. It is also important to consider the experience of the Standing Committee on Security. This committee was founded in 1996 and is composed of senior officials from the ministries of defense and foreign affairs who have held two meetings per year since it was first launched (Flemes 2005). The natural consequence of this military relation was the creation of a binational force: the Cruz del Sur (Southern Cross), which has 1,500 troops participating in United Nations peacekeeping missions (Briones and Alvarez 2008).

The resolution of the main border conflicts, the increasing level of economic exchange, the impact of democracy on civil-military relations, and the presence of new regional institutions for resolving conflicts contribute to create a context where militarized crises or the use of force are unlikely - in other words, a zone of positive peace.

\section{Concluding remarks}

Interstate disputes have returned to South America. However, the regional context of this new generation of boundary disputes is very different from the one that existed when negative peace prevailed. In that period, the only limit to 
military escalation was the presence of a tradition of peaceful settlement of disputes. In zones of hybrid peace the limits have increased. Democracy has fostered the creation and support of all South American countries to new regional institutions of conflict resolution such as UNASUR and the SADC. Democracy has also allowed these countries to know and understand their neighbors' intentions, especially concerning the use of force. Furthermore, the existence of strong trade and investments relations in the present and a high expectation of continuity in the future have strengthened domestic groups whose main interest is the maintenance and deepening of the status quo.

This classical triad of democracy, trade, and institutions operates as a set of breaks that are activated when a dispute emerges. Owing to this, they significantly raise the costs of using force. The low probability of war in zones of positive or hybrid peace explains the lack of interest by Peru, Colombia, or Argentina in purchasing arms in response to the interest of their neighbors in doing so. This is a rational calculation based on the assumption that relative military advantages cannot be exploited in such contexts. For this reason, the phenomenon of an arms race can only take place in a zone of negative peace, where states seek to maintain military balance with their adversaries, where war is still likely.

The probability of the use of force in zones of negative, hybrid, and positive peace is an indicator that the security dilemma is not a homogeneous phenomenon. The type of peace that prevails in each region produces different intensity in this dilemma. In areas of negative peace, the dilemma is intense and the use of force remains an option for states. In hybrid zones, the dilemma is moderated. Conflicts persist but the effect of the triad gives greater certainty about the extent of the use of force. In cases of positive peace, the security dilemma is attenuated. States have abandoned the option of using force as a means to resolve disputes with neighboring nations. In such cases, arms purchases, regardless of their size or destructive potential, will not cause concern among members of the zone due to the strong network of political, economic, and security relations that make the outbreak of a military conflict very unlikely.

\section{Bibliographic references}

BRIONES, Briones \& Rodrigo Álvarez V (2008) ¿Construyendo Confianzas? Fronteras, FFAA y politica en América Latina. Santiago de Chile: FLACSO.

BUZAN, Barry, Ole Waever \& Jaap de Wilde (1998) Security: A New Framework For Analysis. Boulder: Lynne Rienner, 1998.

BUZAN, Barry \& Ole Weaver (2003) Regions and Powers. The Structure of International Security. Cambridge: Cambridge University Press.

CENTENO, Miguel A (2002) Blood and War: War and the Nation-State in Latin America. University Park: Pennsylvania State University Press. 
COPELAND, Dale C (1998) Economic Interdependence and War: A Theory of Trade Expectations. In: Michael E. Brown (ed.) Theories of War and Peace. Cambridge, Mass.: MIT Press, 464-500.

DOMINGUEZ, Jorge; David Mares, Manuel Orozco, David Scott Palmer, Francisco Rojas Aravena \& Andrés Serbin 2003 Boundary Disputes in Latin America. Peaceworks 50. Washington: United States Institute of Peace.

DOYLE, Michael (1997) Ways of War and Peace. New York: W.W. Norton.

ERAZO, Paul Mena (2009) Unasur acepta garantía de Colombia y Estados Unidos. BBC Mundo 28 November. Available at <http://www.bbc.co.uk/mundo/america latina/2009/11/091127_0043_unasur_quito_jg.shtml>, accessed March 29, 2011.

FAIRLIE, Alan; Sandra Queija \& Milagros Rasmussen (2007) Relaciones Económicas Perú-Chile: Integración o Conflicto? Lima: Pontifica Universidad Católica del Perú.

FLEMES, Daniel (2005) Creating a Regional Security Community in Southern Latin America: The Institutionalisation of the Regional Defence and Security Policies. Working Papers: Global and Area Studies 13. Hamburg: German Overseas Institute.

FUENTES, Claudio (1996) Chile-Argentina: el proceso de construir confianza. Working Paper. Santiago: Nueva Serie FLACSO-Chile.

GALTUNG, Johan (1975) Essays in Peace Research. Vol. 1. Copenhagen: Christian Ejlers.

GOVERMENT OF CHILE (2011) Dirección de Relaciones Económicas Internacionales. Inversión directa de Chile en el exterior: Perú. Available at $<\mathrm{http} / / \mathrm{rc}$.direcon.cl/inversion/1429>, accessed March 25, 2011.

GOVERNMENT OF CHILE (2011a) Dirección de Relaciones Económicas Internacionales. Inversión directa de Chile en el exterior: Argentina. Available at <http://rc.direcon.cl/ inversion/1429>, accessed March 28, 2011.

HIRST, Mónica (2003) Seguridad regional en las Américas < Regional Security in the Americas]. In: Wolf Grabendorff (ed.) La seguridad regional en las Américas. Bogotá: Friedrich Ebert Stiftung.

HOLSTI, Halevi J (1996) The State, War and the State of the War. Cambridge: Cambridge University Press.

HORNA, Angel (2009) Maritime Dispute (Peru vs Chile): Background and Preliminary Thoughts. In: Chircop, Aldo; Coffen-Smout \& Moira McConnell (eds.) Ocean Yearbook 23. Leiden: Martinus Nijhoff Publishers.

HURRELL, Andrew (1998) An emerging security community in South America? In: Emanuel Adler \& Michael Barnett (eds.) Security communities. Cambridge: Cambridge University Press, $137-154$.

IADB (Inter-American Development Bank) (2011) Statistic and Databases: DataIntal, bilateral trade Colombia-Venezuela. Available at <http://www.iadb.org/dataintal/BalanzaComercial. aspx>, accessed March 15, 2011.

IADB (2011a) Statistic and Databases: DataIntal, bilateral trade Chile-Peru. Available at <http:// www.iadb.org/dataintal/BalanzaComercial.aspx>, accessed March 19, 2011. 
INTERNATIONAL PEACE RESEARCH INSTITUTE \& UPPSALA CONFLICT DATA PROGRAM (2011) Armed Conflict Dataset and Uppsala Conflict Data Program. Available at <http://www.nsd.uib.no/macrodataguide/set.html?id=55\&sub=1>, accessed March 23, 2011.

JONES, Daniel M., BREMER, Stuart A. and SINGER, J. David, 'Militarized Interstate Disputes, 1816-1992: Rationale, Coding Rules, and Empirical Patterns', Conflict Management and Peace Science, 15(2), December 1996, pp. 163-213.

KACOWICZ, Arie M (1998) Zones of Peace in the Third World: South America and West Africa in Comparative Perspective. Albany: State of New York Press.

KACOWICZ, Arie M (2005) The Impact of Norms in International Society: The Latin American Experience, 1881-2001. Notre Dame: University of Notre Dame Press.

KAHHAT, Farid (2008) ¿Guerra Fría en los Andes?. Foreign Affairs Latinoamérica 8 (3) (Julio): $2-11$.

KEOHANE, Robert (1984) After Hegemony: Cooperation and Discord in the World Political Economy. Princeton: Princeton University Press.

KYDD, Andrew (1997) Sheep in Sheep's Clothing: Why Security Seekers Do Not Fight

Each Other. Security Studies 7(1): 114-154.

MACDERMOTT, Jeremy (2009) Colombia’s rocky regional relations. BBC News 30 July. Available at <http://news.bbc.co.uk/2/hi/americas/8176314.stm>, accessed July 27, 2010.

MANSFIELD, Edward D \& Brian M Pollins (2001) The study of interdependence and conflict. Journal of Conflict Resolution 45 (2): 834-859.

MARES, David R (2001) Violent Peace: Militarized Interstate Bargaining in Latin America. New York: Columbia University Press.

MARTIN, Felix (2006) Militarist Peace in South America. Nueva York: Palgrave.

MILlER, Benjamín (2007) States, Nations, and the Great Powers: The Sources of Regional War and Peace. Cambridge: Cambridge University Press.

MONTOYA, José Robles (2006) De la disuasión a la cooperación: dos siglos en la relación Perú-Chile. Fuerzas Armadas y Sociedad 20 (1): 31-50.

NORDEN, Deborah L (1996) Military Rebellion in Argentina: Between Coups and Consolidation. Lincoln and London: University of Nebraska Press.

OELSNER, Andrea (2007) Friendship, Mutual Trust and the Evolution of Regional Peace in the International System. Critical Review of International Social and Political Philosophy 10 (2) (June): 257-279.

ONEAL, John R \& Bruce M Russett (1997) The Classical Liberals were right: democracy, interdependence, and conflict 1950-1985. International Studies Quarterly 41 (2): 267-293.

PERÚ 21 (2011) Inversión peruana en Chile crecerá 20\% <http://peru21.pe/noticia/702709/ inversion-peruana-chile-crecera-20] (accessed March 26 2011).

RAMIREZ, Socorro. Colombia-Venezuela: entre episodios de cooperación y predominio del conflicto. In: Jorge Domínguez (ed.) Conflictos territoriales y democracia en América Latina. Buenos Aires: Siglo Veintiuno, 203-276. 
ROSENCRANCE, Richard \& Peter Thompson (2003) Trade, Foreign Investment, and Security. Annual Review Political Science 6: 377-398.

RUSSETT, Bruce (1993) Grasping the Democratic Peace. Princeton: Princeton University Press.

RUSSETT, Bruce M \& John Oneal (2001) Triangulating Peace: Democracy, Interdependence, and International Organization. New York: Norton.

SALAZAR, Hernando (2010) Colombia y Venezuela reanudan relaciones BBC Mundo 11 August; available at <http://www.bbc.co.uk/mundo/america_latina/2010/08/100810_0142_ venezuela_colombia_relaciones_gz.shtml>, accessed March 24, 2011.

SCHWELLER, Randall L (2004) Unanswered Threats. A neoclassical Realist Theory of Underbalancing. International Security 29 (2) (Fall): 159-201.

SMINK, Veronica (2010) Chile y Perú rompen el hielo. BBC Mundo 26 November. Available at <http:/www.bbc.co.uk/mundo/noticias/2010/11/101125_chile_peru_relaciones_presidentes_ visita_jg.shtml>, accessed March 22, 2011.

SADC (2010). Action Plan 2010-2011. Available at <http://www.cdsunasur.org/index. php?option=com_content $\&$ view=article $\& i d=333 \&$ Itemid $=261 \&$ lang=es $>$, accessed January $10,2011$.

ZIRKER, Daniel \& Joao Martins Filho (2000) Nationalism, National Security and Amazônia: Military Perceptions and Attitudes in Contemporary Brazil. Armed Forces and Society 27 (1) (Fall): 105-129.

Received May 6, 2012

Accepted July 18, 2012

\section{Abstract}

South America's predominant democratic regimes and its increasing interdependence on regional trade have not precluded the emergence of militarized crises between Colombia and Venezuela or the revival of boundary claims between Chile and Peru. This way, how can we characterize a zone that, in spite of its flourishing democracy and dense economic ties, remain involved in territorial disputes for whose resolution the use of force has not yet been discarded? This article contends that existing classifications of zones of peace are not adequate to explain this unusual coexistence. Thus, its main purpose is to develop a new analytical category of regional peace for assessing this phenomenon: the hybrid peace. It aims to research the evolution of security systems in South America during the previous century and build a new, threefold classification of peace zones: negative peace zones, hybrid peace zones, and positive peace zones.

Keywords: democracy; hybrid peace; South America; zones of peace.

\section{Resumo}

O fato de os países sul-americanos possuírem regimes predominantemente democráticos e apresentarem uma interdependência cada vez maior não evitou que houvesse tensões militares entre Colômbia e Venezuela ou que ressurgissem conflitos de fronteira entre Chile e Peru. 
Assim sendo, como se caracterizaria uma região que, apesar do clima democrático crescente e dos densos laços econômicos, permanece imersa em disputas territoriais cuja resolução tem sido frequentemente pensada com referências ao uso da força? Por meio do presente artigo, argumenta-se que as tipologias existentes sobre zonas de paz não são adequadas para explicar essa contradição. Para tanto, o propósito principal do trabalho é desenvolver uma categoria analítica nova de paz regional, a paz híbrida, para analisar esse fenômeno. A intenção é pesquisar a evolução dos sistemas de segurança na América do Sul durante o último século e construir uma nova classificação de zonas de paz em três tipos: zonas de paz negativas, zonas de paz híbridas, e zonas de paz positivas.

Palavras-chave: democracia; paz hibrida; América do Sul; zonas de paz. 